\title{
A 24-month follow-up of the metabolic profile of Greek HIV (+) population on lopinavir/ritonavir-based regimen: the ACA GREC trial
}

\author{
SM Metallidis*1, ML Lazanas², PG Gargalianos³, H Sambatakou4, \\ NM Magafas², GX Xilomenos ${ }^{3}$, PP Panagopoulos ${ }^{5}$, MG Giannaris ${ }^{4}$, \\ GB Bakoyiannis ${ }^{6}$, KX Xynos7 ${ }^{7}$ HG Gogos ${ }^{8}$, HB Bassaris ${ }^{8}$, HG Giamarellou ${ }^{5}$, \\ PN Nikolaidis ${ }^{1}$, SK Kourkoudi ${ }^{9}$ and KL Loyo ${ }^{9}$
}

\begin{abstract}
Address: ${ }^{1}$ Ahepa Hospital, Thessaloniki, Greece, ${ }^{2}$ Erythros Stavros Hospital, Athens, Greece, ${ }^{3} \mathrm{G}$ Genimatas Hospital, Athens, Greece, ${ }^{4}$ Ipokratio Hospital, Athens, Greece, ${ }^{5}$ Attikos Hospital, Athens, Greece, ${ }^{6}$ University of Athens Medical School, Athens, Greece, ${ }^{7}$ Abbott Labs Hellas, Athens, Greece, ${ }^{8}$ Rio University Hospital, Patras, Greece and ${ }^{9}$ A Sygros Hospital, Athens, Greece

* Corresponding author
\end{abstract}

from Ninth International Congress on Drug Therapy in HIV Infection

Glasgow, UK. 9-13 November 2008

Published: 10 November 2008

Journal of the International AIDS Society 2008, I I (SuppI I):PI24 doi:I0.II86/I758-2652-I I-SI-PI 24

This abstract is available from: http://www.jiasociety.org/content/I I/SI/PI24

(c) 2008 Metallidis et al; licensee BioMed Central Ltd.

\section{Purpose of the study}

Use of protease inhibitors has been associated with plasma lipids and glucose changes. Co-formulated lopinavir/ritonavir (LPV/r) is a potent antiretroviral drug. However, it has been implicated in lipid and glucose abnormalities. We evaluated changes in lipids and glucose in HAART naïve and experienced patients enrolled in a clinical trial of LPV/r-based regimen.

\section{Methods}

This prospective, 24-month, open label, phase IV, multicenter study, comprised of 131 Greek HIV+ subjects randomized into two groups according to PI and HAART history. Group A $(\mathrm{N}=91)$ included antiretroviral- or PInaïve subjects who initiated a $\mathrm{LPV} / \mathrm{r}$-based regimen, and group B $(\mathrm{N}=40)$ included PI-experienced subjects who switched their regimen to include LPV/r. All subjects underwent clinical and laboratory evaluation (total cholesterol [TC], triglycerides [TG], LDL, HDL, ApoB, glucose) at baseline and at 3, 6, 12, 18 and 24 months of follow-up. Changes in laboratory parameters were compared within and between the two groups using linear mixed effects models.

\section{Summary of results}

Mean fasting glucose levels declined from baseline to 24 months value of $10.3 \mathrm{mg} / \mathrm{dl}(\mathrm{p}=0.002)$ in group B while remaining unchanged in group $\mathrm{A}$. TG and TC levels were higher at baseline in group B compared to group A with higher baseline levels associated with higher end values for both groups. Both markers tended to increase during follow up, but never reached toxicity limits as defined by CTCAE v3.0. TG increased $0.1 \log 10 \mathrm{mg} / \mathrm{dl}(\mathrm{p}<0.001)$ from baseline in group A with no change in group B. CD4+ cell levels at baseline of 80-350 resulted in lower TG levels. A mean increase of $36.1 \mathrm{mg} / \mathrm{dl}(\mathrm{p}<0.001)$ and $24.9 \mathrm{mg} / \mathrm{dl}(\mathrm{p}=0.004)$ for group A and B, respectively, was observed for TC at 24 months. HDL showed a statistically significant mean increase of $6.2 \mathrm{mg} / \mathrm{dl}(\mathrm{p}=0.001)$ for group $A$ and a $5.1 \mathrm{mg} / \mathrm{dl}$ indicative increase for group $\mathrm{B}(\mathrm{p}=0.071)$. TC/HDL ratio remained below 5 throughout the study. ApoB values showed a $31.3 \mathrm{mg} / \mathrm{dl}$ mean increase $(\mathrm{p}<0.05)$ in group A.

\section{Conclusion}

Minimal differences were observed in fasting glucose and lipid profile between HAART naïve and experienced subjects receiving LPV/r in a 2-year study period. The TC and 
TG increase observed never reached toxicity levels. TC/ HDL, an important predictor of cardiovascular event occurrence, remained below the critical value 5 for the whole period. Severity of condition as defined by the baseline CD4+ count affects TG levels.

Publish with Bio Med Central and every scientist can read your work free of charge

"BioMed Central will be the most significant development for disseminating the results of biomedical research in our lifetime. " Sir Paul Nurse, Cancer Research UK

Your research papers will be:

- available free of charge to the entire biomedical community

- peer reviewed and published immediately upon acceptance

- cited in PubMed and archived on PubMed Central

- yours - you keep the copyright

Submit your manuscript here:

http://www.biomedcentral.com/info/publishing_adv.asp 